\title{
Cultural and Pathogenic Variability of the Different Isolates of Rhizoctonia solani Causing Root Rot of Cotton Collected from Rajasthan
}

\author{
Ramniwas Yadav ${ }^{*}$, R. N. Bunker², Kalpana Yadav², \\ Sushila Choudhary ${ }^{1}$ and Shankar Lal Yadav ${ }^{3}$
}

\author{
${ }^{1}$ Division of Plant Pathology, RARI, Durgapura, SKN Agriculture University, \\ Jobner, Jaipur, Rajasthan, India \\ ${ }^{2}$ Department of Plant Pathology, Rajasthan College of Agriculture, MPUAT\&T, \\ Udaipur - 313001, India \\ ${ }^{3}$ SKN College of Agriculture, Jobner, Jaipur, Rajasthan, India \\ *Corresponding author
}

\section{A B S T R A C T}

\begin{tabular}{|c|}
\hline Keywords \\
\hline $\begin{array}{l}\text { Rhizoctonia solani, } \\
\text { Sclerotia, } \\
\text { Morphology, } \\
\text { Pathogenic } \\
\text { variability, Cultural } \\
\text { characters, etc. }\end{array}$ \\
\hline Article Info \\
\hline $\begin{array}{l}\text { Accepted: } \\
20 \text { January } 2020 \\
\text { Available Online: } \\
10 \text { February } 2020\end{array}$ \\
\hline
\end{tabular}

The present study was undertaken on integrated management of root rot of cotton caused by Rhizoctonia solani to know the disease incidence; survey was carried out during 2017 in 18 villages of different six cotton growing district viz., Udaipur, Hanumangarh, Sri Ganganagar, Chittorgarh, Banswara and Dungarpur. Cultural and morphological variability of each isolates was tested under laboratory condition to find out the aggressiveness of the pathogens (isolates) and results find out that isolate SNG Rs-03 from Sri Ganganagar was the most virulent compare to other isolates. Isolate of Sri Ganganagar (SNS Rs-03) had $90 \mathrm{~mm}$ growth diameter (fast growing) with cottony white growth, aerial at centre with zonation, abundant and submerged sclerotia production. Among the different isolates of $R$. solani, sclerotia of CHT Rs-04 were the largest in size measuring 1.8 (1.5$2.0) \times 1.2(0.9-1.4) \mathrm{mm}$, Pathogenic variability and disease symptomology among six isolates was test on cotton cultivar "Jai BG-II" growing in cage house and results observed that isolate from Sri Ganganagar (SNG Rs-03) highly aggressive with high degree of symptoms.

\section{Introduction}

Cotton (Gossypium spp.) is one of the most important fibers and cash crop belongs to genus Gossypium of the family Malvaceae. It is originated as a tropical and subtropical perennial plant, but is produced as an annual crop in many temperate regions around the world. Cotton is cultivated in about 80 countries in the world in which top five producers are India, China, Pakistan, USA and Brazil (Anonymous, 2016-17). In year 2000, cotton was cultivated in 130 countries and estimated $2.5 \%$ of the worlds arable land area, making it one of the most important crops in term of land use after food grains and soybean 
(Weiss, 2000). India is the first largest cotton producer, consumer and exporter in the world, it is cultivated in an area about 11.87 million hectares with the 30.15 million tons production and $4.32 \mathrm{q}$ ha $^{-1}$ productivity respectively, Agriculture statistics at a glance2016 (2017-a). In India, there are 9 major cotton growing states which fall into three zone viz.- Northern zone (Punjab, Haryana and Rajasthan), central zone (Maharashtra, Madhya Pradesh and Gujarat) and southern zone (Andhra Pradesh, Karnataka and Tamil Nadu), (Anonymous, 2013-14). In Rajasthan total area under cotton cultivation is around 4.4 lac hectares with production of 13.2 lac tones and productivity of $5.01 \mathrm{q} \mathrm{ha}^{-1}$, Agriculture statistics at a glance-2016 (2017b).

Cotton production is threatened by a large number of diseases caused fungi and bacteria. Most common bacterial diseases of cotton are bacterial blight (Xanthomonas campestris $p v$. Malvacearum), Crown gall (Agrobacterium tumefaciens) and lint degradation (Erwinia herbicola). Most common fungal diseases are leaf spot and leaf blight caused by (Alternaria macrospora, Alternaria alternata, Cercospora gossypina, Cochiobolus spicifera, Myrothecium roridum (Kamal and Moghal, 1968; Jagirdar and jagirdar, 1980; Jiskani 1992 and jaskani 2001). Anthracnose (Colletotrichum gossypii), Areolate mildew (Cercosporella gossypii), Ascochyta blight (Ascohyta gossypii) and black root rot (Thielaviopsis basicola), boll rot is caused by several pathogen including (Ascohyta gossypii, Colletotrichum gossypii, Fusarium spp., Lasiodiplodia theobromae, Rhizoctonia solani). Under favorable environmental condition Charcoal rot (Macrophomina phaseolina), Fusarium wilt Fusarium oxysporum f. sp. vasinfectum), powdery mildew (Leveillula taurica), cotton rust (Puccinia schedonnardii, Puccinia cacabata), Sclerotium stem rot (Sclerotium rolfsii) and Damping-off and root rot (Rhizoctonia solani
(Silva et al., 1995 and Belot and Zambiasi, 2007).

Among the seedling diseases, damping-off and root rot of cotton caused by Rhizoctonia solani showed heavy losses particularly during the early stage of crop growth (Nawar, 2008), plant stand and significant losses in cotton production throughout the cotton growing countries of the world (Michael et al., 2007, Koenning, 2008).

Rhizoctonia is a widespread, destructive and versatile plant pathogen, are distributed worldwide in both agriculture and forest soils and are known to cause root diseases of several crop plants (Gracia et al., 2006). The severity of this disease varies from locality to locality and attends maximum intensity (up to $90 \%$ ) during rainy season in cotton (Singh and Verma 1988). The soil moisture of 20 per cent and temperature of $35{ }^{\circ} \mathrm{C}$ have been reported most suitable for infection (Monga and Sheoraj, 1994; Haq et al., 1999).

Root rot of cotton symptoms include seed decay, decay of the seedling before emergence, partial or complete girdling of the emerged seedling stems, and seedling root rot are common. Damaged seedlings that emerge are pale with sore shine, stunted, slower growing and sometimes die within a few days (Heydary et al., 2005; Watkins 1981).

\section{Materials and Methods}

The investigations on "Integrated Management of Root Rot of Cotton Caused by Rhizoctonia solani (Kuhn)" was carried out at the Department of Plant Pathology, Rajasthan College of Agriculture (RCA), Udaipur during 2016-17.

\section{Survey for collection of diseased samples}

The diseased samples of cotton showing typical root rot symptoms were collected in 
Kharif season of 2016 from farmer's fields of different cotton growing areas of Rajasthan viz., Udaipur, Dungarpur, Banswara and Chittorgarh (Southern Rajasthan) and Shri Ganganagar, Hanumangarh districts (Northern Rajasthan) all from local land races.

\section{Isolation, purification and identification of pathogen}

The pathogens were isolated on potato dextrose agar (PDA) medium. Small pieces (1-2 mm) of diseased roots were cut, washed with sterilized water, surface sterilized with 0.1 per cent mercuric chloride $\left(\mathrm{HgCl}_{2}\right)$ solution for 1 minutes followed by three to four washings with sterilized distilled water and were transferred aseptically to 2 per cent PDA (Potato Dextrose Agar) poured Petriplates. The plates were incubated in an incubator at $28 \pm 1{ }^{0} \mathrm{C}$ for 7 days. Hyphae coming out from the bits were sub-cultured on the fresh PDA in Petri dishes. From these bits mostly cultures of Rhizoctonia solani Sclerotium spp. and Fusarium oxysporium were recovered. The culture of Rhizoctonia was purified by single hyphal-tip method and that of Fusarium by single spore method using a dummy objective.

The cultures were identified by comparing the morphological and cultural characters described in standard references Mordue (1988) for Rhizoctonia and Booth (1971) for Fusarium, and were identified as Rhizoctonia solani and Fusarium oxysporium. Most of the samples collected from different locations were yielded colonies of fungus Rhizoctonia, while some samples were also yielded Fusarium and Sclerotium spp. colonies. Thus we used fungus $R$. solani for pathogenicity test in this research work.

\section{Pathogenicity test}

Pathogenicity of the isolated cultures of $R$. solani was tested by growing cotton plants in pots containing pathogen-infested soil. The pathogens (isolates) of $R$. solani were separately multiplied on corn meal-sand (1:1) medium at $28 \pm 1^{0} \mathrm{C}$ for 10 days and then it was mixed separately with sterilized soil @ 20 $\mathrm{g} / \mathrm{kg}$ soil. This inoculated soil was filled in sterilized pots $(20 \mathrm{~cm}$ face diameter). The pots filled with inoculated soil were kept in the cage house for 7 days and were irrigated with sterile water to allow establishment of the pathogen. Surface sterilized seeds $(0.1$ per cent mercuric chloride solution for 2 minutes) of susceptible cotton cultivar "Jai BG-II" were sown in inoculated pots@10 seeds / pot, keeping four pots as four replications for each isolate (pathogen). For comparison seeds were sown in sterilized soil, without pathogen (uninoculated control). The pots were irrigated on alternate days with sterilized water to provide good moisture.

The typical symptoms of root rot started on $10^{\text {th }}$ day and fully manifested within 30 days. The diseased plant collar region and roots were showed black and yellowish lesions and shrunk. From the wilted seedlings showing black and yellowish lesions of roots, reisolation of the pathogen $R$. solani was attempted, and the cultures were readily reisolated. In checks, healthy cotton plants continued to grow. The culture were purified and maintained on PDA slants at $4^{\mathrm{C}} \mathrm{C}$ for further studies.

\section{Cultural variability and morphological variability}

Six isolates of $R$. solani were grown on potato dextrose agar (PDA). The autoclaved medium was dispensed in Petri plates and allowed to solidify. Three $\mathrm{mm}$ disc of the individual isolates of $R$. solani removed from the periphery of seven days old culture was aseptically placed in the centre of the PDA agar plate, keeping three plates of each plate 
as three replications for each isolate. The plates were incubated at $28 \pm 1{ }^{0} \mathrm{C}$. The variations in growth pattern and colony growth (diameter) of fungi in all isolates were recorded. Sclerotial production (quantity of sclerotia) by isolates of $R$. solani was determined by removing agar-plugs $(3 \mathrm{~mm}$ diameter) from three liner spots across the centre of the colony, which were suspended in $10 \mathrm{ml}$ sterile water in glass taste tube and agitated twice for about ten seconds each time on a vortex shaker to dislodge sclerotia.

The number of sclerotia in the resultant suspensions was counted by naked eyes and for microsclerotia use a haemocytometer, and expressed as quantity of sclerotia. For sclerotial size (length and width) mounts were prepared in aniline-blue lacto-phenol and measurements were taken by measuring 50 sclerotia of each isolates of $R$. solani using stage and ocular micrometer.

\section{Pathogenic and symptomatological variability}

Pathogenic and symptomatological variability of six isolates of $R$. solani was carried out under cage house in pot culture, the isolated cultures of $R$. solani was tested by growing cotton plants in pots containing pathogeninfested soil. The pathogens (isolates) of $R$. solani were separately multiplied on corn meal-sand (1:1) medium at $28 \pm 1^{0} \mathrm{C}$ for 10 days and then it was mixed separately with sterilized soil @ $20 \mathrm{~g} / \mathrm{kg}$ soil. This inoculated soil was filled in sterilized pots $(20 \mathrm{~cm}$ face diameter).

The pots filled with inoculated soil were kept in the cage house for 7 days and were irrigated with sterile water to allow establishment of the pathogen. Surface sterilized seeds (0.1 per cent mercuric chloride solution for 2 minutes) of susceptible cotton cultivar "Jai BG-II" were sown in inoculated pots @ 10 seeds/pot, keeping four pots as four replications for each isolate (pathogen). For comparison seeds were sown in sterilized soil, without pathogen (uninoculated control). The pots were irrigated on alternate days with sterilized water to provide good moisture. The typical symptoms of root rot started on $10^{\text {th }}$ day and fully manifested within 30 days. Severity and symptoms by respective isolates was recorded carefully.

\section{Results and Discussion}

\section{Isolation of the pathogen, Purification and identification of the pathogen}

The disease samples of cotton root rot were also collected from different villages of six districts during the surveys to isolate the pathogen. The most of root rot samples yielded Rhizoctonia, Fusarium spp. and Sclerotinia spp., whereas, in majority of $R$. solani colonies were recovered.

To purify $R$. solani single sclerotia was picked under a stereo-binocular microscope and using single hyphal tip culturing on PDA plates. The cultures of different isolates were identified on the basis of morphological characters of the fungus and compared with the standard description (Holiday, 1981 and Mordue, 1988).

\section{Variability among the isolates of $\boldsymbol{R}$. solani}

Variability is a natural process in living organism. In present investigations variability among six isolates of $R$. solani was studied. They were subjected to study the cultural characters (colour, shape, and diameter of colony), sclerotial morphology (size, quantity and location).

\section{Studies on cultural and morphological characteristics of $R$. solani}

Six isolates of $R$. solani were cultured on PDA and cultural characteristics of the pathogen recorded at $7^{\text {th }}$ day of incubations. 
Table.1 Radial growth and cultural characters of six isolates of $R$. Solani

\begin{tabular}{|c|c|c|c|c|}
\hline $\begin{array}{l}\text { S. } \\
\text { No. }\end{array}$ & Isolates & $\begin{array}{l}\text { Colony } \\
\text { diameter } \\
\left(\mathbf{m m}^{*}\right)\end{array}$ & $\begin{array}{l}\text { Sclerotial } \\
\text { production }\end{array}$ & $\begin{array}{l}\text { Colony Growth characters and colony colour in } \\
\text { petri plates }\end{array}$ \\
\hline 1. & $\begin{array}{l}\text { UDP } \\
\text { Rs-01 }\end{array}$ & 83 & +++ & $\begin{array}{l}\text { Cottony, irregular margins, medium to fast growing, } \\
\text { dully brownish to black, zonation absent, } \\
\text { microscopic sclerotia present in culture. }\end{array}$ \\
\hline 2. & $\begin{array}{l}\text { HMG } \\
\text { Rs-02 }\end{array}$ & 88 & - & $\begin{array}{l}\text { Velvety, suppressed at centre, zonation present, fast } \\
\text { growing, yellowish white in colour, only mycelial } \\
\text { aggregation found (no true sclerotia formed in } \\
\text { culture) }\end{array}$ \\
\hline 3. & $\begin{array}{l}\text { SNG } \\
\text { Rs-03 }\end{array}$ & 90 & ++++ & $\begin{array}{l}\text { Cottony, aerial felty in centre, zonation present, fast } \\
\text { growing, abundant and submerged sclerotia. }\end{array}$ \\
\hline 4. & $\begin{array}{l}\text { CHT } \\
\text { Rs-04 }\end{array}$ & 90 & +++ & $\begin{array}{l}\text { White to dirty white in colour, fast growing with } \\
\text { suppressed mycelium, zonation present, maximum } \\
\text { sclerotia formed at centre, maximum size and } \\
\text { abundant sclerotial production, }\end{array}$ \\
\hline 5. & $\begin{array}{l}\text { BNS } \\
\text { Rs-05 }\end{array}$ & 60 & + & $\begin{array}{l}\text { Very slow growing, light white in colour, zonation } \\
\text { absent, suppressed mycelium, medium size, centric } \\
\text { as well as scattered and moderate in number } \\
\text { sclerotial production }\end{array}$ \\
\hline 6. & $\begin{array}{l}\text { DNG } \\
\text { Rs-06 }\end{array}$ & 84 & ++ & $\begin{array}{l}\text { Medium to fast growing, white to dirty white in } \\
\text { colour, zonation absent, suppressed mycelium, small } \\
\text { and few sclerotial production at marginal. }\end{array}$ \\
\hline \multicolumn{2}{|c|}{ SEm \pm} & \multicolumn{3}{|l|}{1.599} \\
\hline \multicolumn{2}{|c|}{$\mathrm{CD}(P=0.05)$} & \multicolumn{3}{|l|}{4.98} \\
\hline
\end{tabular}

*Mean of three replications $(-=$ No sclerotia $;+=$ Few; $++=$ Moderate $;+++$ or above $=$ Abundant $)$ 
Table.2 Variation in sclerotial morphology of the isolates of $R$. solani on PDA

\begin{tabular}{|c|c|c|c|c|c|c|}
\hline \multirow[t]{3}{*}{ S.No. } & \multirow[t]{3}{*}{ Location } & \multirow[t]{3}{*}{ Isolates } & \multicolumn{4}{|c|}{ Size of sclerotia $\left(\mathrm{mm}^{*}\right)$} \\
\hline & & & \multicolumn{2}{|c|}{ Length } & \multicolumn{2}{|c|}{ Width } \\
\hline & & & Mean & Range & Mean & Range \\
\hline 1. & Udaipur & UDP Rs-01 & $0.5 \pm 0.06$ & $0.4-06$ & $0.3 \pm 0.09$ & $0.1-0.4$ \\
\hline 2. & Hanumangarh & HMG Rs-02 & $\begin{array}{l}0.0 \pm 0.0 \\
\text { (a) }\end{array}$ & $\begin{array}{l}0.0 \\
\text { (a) }\end{array}$ & $\begin{array}{l}0.0 \pm 0.0 \\
\text { (a) }\end{array}$ & $\begin{array}{l}0.0 \\
\text { (a) }\end{array}$ \\
\hline 3. & Sri Ganganagar & SNG Rs-03 & $1.6 \pm 0.14$ & $1.3-1.8$ & $1.1 \pm 0.06$ & $1.0-1.2$ \\
\hline 4. & Chhitorgarh & CHT Rs-04 & $1.8 \pm 0.14$ & $1.5-2.0$ & $1.2 \pm 0.15$ & $0.9-1.4$ \\
\hline 5. & Banswara & BNS Rs-05 & $0.9 \pm 0.11$ & $0.7-1.1$ & $0.3 \pm 0.13$ & $0.2-0.6$ \\
\hline 6. & Dungarpur & DNG Rs-06 & $1.3 \pm 0.11$ & $1.1-1.5$ & $0.7 \pm 0.09$ & $0.6-0.9$ \\
\hline \multicolumn{3}{|c|}{ SEm \pm} & \multicolumn{2}{|c|}{0.110} & \multicolumn{2}{|c|}{0.100} \\
\hline \multicolumn{3}{|c|}{$\mathrm{CD}(P=0.05)$} & \multicolumn{2}{|c|}{0.34} & \multicolumn{2}{|c|}{0.32} \\
\hline
\end{tabular}

$*$ Mean no. of 50 sclerotia and \pm S.D. of mean value. $(a)=$ no sclerotia present

Table.3 Pathogenic and symptomatological variability among six isolates of R. solani on cotton cultivar "Jai BG-II"

\begin{tabular}{|c|c|c|c|}
\hline $\begin{array}{l}\text { S. } \\
\text { No }\end{array}$ & Isolate code & $\begin{array}{l}\text { Per cent } \\
\text { incidence* }\end{array}$ & Typical symptoms \\
\hline 1. & UDP Rs-01 & $\begin{array}{c}18.0 \\
(25.0)\end{array}$ & $\begin{array}{l}\text { Yellowing or bronzing of leaves followed by wilting, blackish } \\
\text { brown colour lesions, symptoms found on under and upper } \\
\text { ground part of roots, partial secondary roots found. }\end{array}$ \\
\hline 2. & HMG Rs-02 & $\begin{array}{c}24.5 \\
(29.6)\end{array}$ & $\begin{array}{l}\text { Stem girdling at ground level, wire-stem and wilting with } \\
\text { healthy primary and secondary roots. }\end{array}$ \\
\hline 3. & SNG Rs-03 & $\begin{array}{c}52.2 \\
(46.3)\end{array}$ & $\begin{array}{l}\text { Most of the seedling roots are detached at ground level, } \\
\text { brownish large lesions are present on underground roots } \\
\text { including pith, easily pooled out, showed no secondary roots } \\
\text { with high degree of symptoms }\end{array}$ \\
\hline 4. & CHT Rs-04 & $\begin{array}{c}38.6 \\
(38.4)\end{array}$ & $\begin{array}{l}\text { Blackish brown colour lesions, Stem girdling at ground level, } \\
\text { wire-stem and wilting, no secondary roots, root bark easily } \\
\text { removed. }\end{array}$ \\
\hline 5. & BNS Rs-05 & $\begin{array}{c}16.4 \\
(23.9)\end{array}$ & $\begin{array}{l}\text { Most of the rotten lesions found at just upper ground part, } \\
\text { comparatively medium size lesions with pale yellowish colour } \\
\text { and lower degree of symptoms observed. }\end{array}$ \\
\hline 6. & DNG Rs-06 & $\begin{array}{c}20.8 \\
(27.1)\end{array}$ & $\begin{array}{l}\text { Yellowing or bronzing of leaves followed by wilting, medium } \\
\text { size lesions with pale yellowish colour, plant easily pooled out. }\end{array}$ \\
\hline 7. & Control & $\begin{array}{c}0.0 \\
(0.0)\end{array}$ & $\begin{array}{l}\text { White well branched (secondary) roots, no lesions found, } \\
\text { healthy phloem and xylem vessels. }\end{array}$ \\
\hline \multicolumn{2}{|c|}{ SEm \pm} & \multicolumn{2}{|r|}{ J } \\
\hline \multicolumn{2}{|c|}{$\mathrm{CD}(P=0.05)$} & \multicolumn{2}{|l|}{3.26} \\
\hline
\end{tabular}

*mean of four replications, Figures in parentheses are arcsine $\sqrt{ }$ per cent angular transformed values. 

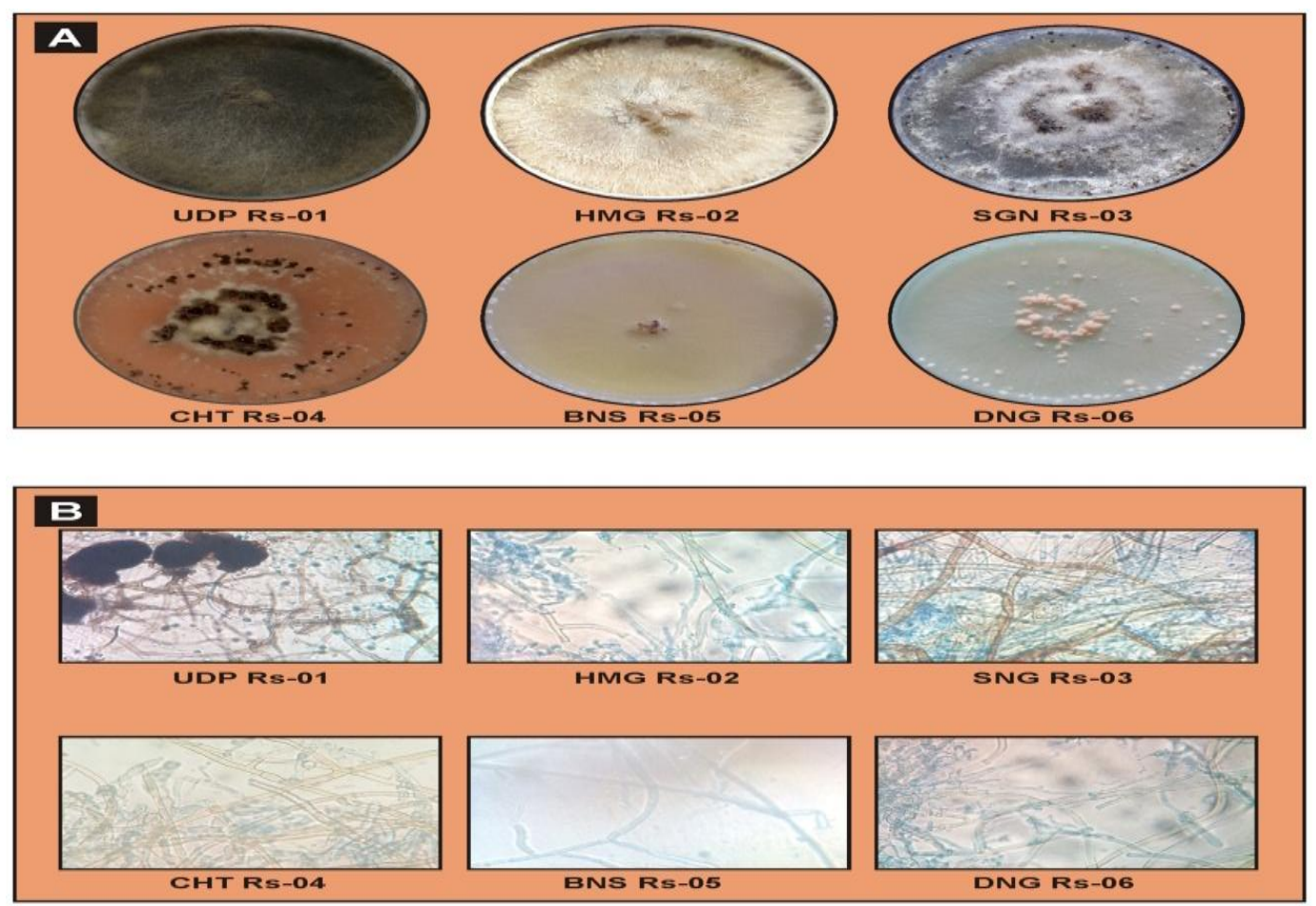

Plate 4: Cultural and morphological variability among six isolates of $R$. solani (A) Variability in culture and sclerotia formation by different isolates of (B) Variation in mycelium and sclerotia of different isolates of $R$. solami at $40 \times$

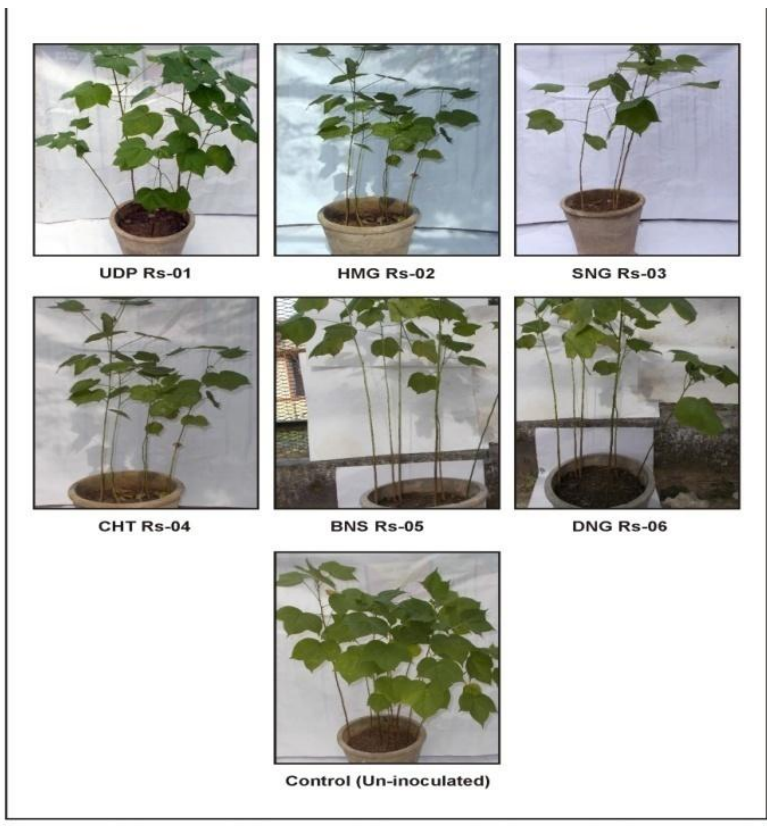

Plate 3: Pathogenic variability of different isolates of $R$. solani on cotton cultivar

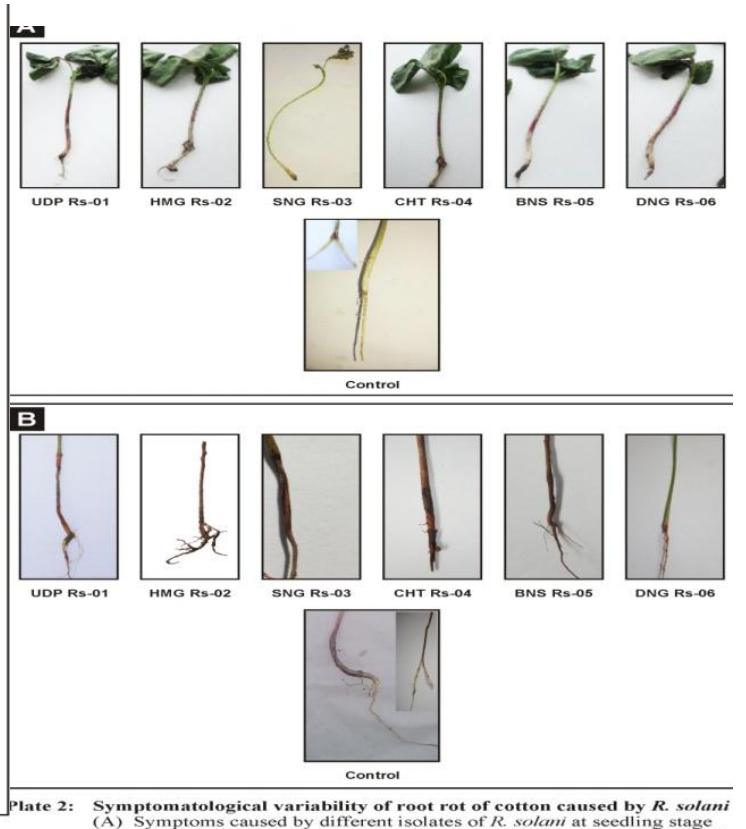

A) Symptoms caused by different isolates of $R$, solami at seedling stage
(B) Symptoms on stem and roots caused by different isolates of $R$ solau at 30 DAS
The results were revealed that all the six isolates of $R$. solani differed in colony characters on $7^{\text {th }}$ day of incubations under medium and uniform environment conditions. The isolate belongs from Udaipur (UDP Rs01) had $83 \mathrm{~mm}$ growth diameter (medium to 
fast growing) with cottony, irregular margins and dully brownish to black in colour, zonation was absent with abundant and very small size sclerotia. Isolate from Hanumangarh (HMG Rs-02) had growth diameter $(88 \mathrm{~mm})$ that was fast growing, velvety, suppressed at centre, zonation present, yellowish white in colour with only mycelial aggregation (no true sclerotia formation). Isolate of Sri Ganganagar (SNS Rs-03) had $90 \mathrm{~mm}$ growth diameter (fast growing) with cottony white growth, aerial at centre with zonation, abundant and submerged sclerotia production. Isolate from Chittorgarh (CHT Rs-04) had white to dirty white culture growth with fast growing suppressed mycelium, zonation present, sclerotia generally maximum sclerotia found at centre. Isolate of Banswara (BNS Rs-05) had $60 \mathrm{~mm}$ growth that was very slow growing, light white in colour, zonation absent, suppressed mycelium and few sclerotial production. Isolate of Dungurpur (DNG Rs-06) was showed medium growth (84.0mm), white to dirty white in colour, zonation absent, suppressed mycelium and centric as well as scattered sclerotia.(Table- 1)

For identification (colony cultural characterscolour, texture and size of sclerotia) characters was compared with the standered reference descriptions (Sneh et al., 1992 and Mordue 1988) for Rhizoctonia solani.

\section{Variability in sclerotial morphology}

Sclerotial formation was recorded in five isolates of $R$. solani except Hanumangarh (HMG Rs-02). Morphology of sclerotia especially varies in terms of length and width among different isolates collected from various locations. Among the different isolates of $R$. solani, sclerotia of CHT Rs-04 were the largest in size measuring 1.8 (1.5$2.0) \times 1.2(0.9-1.4) \mathrm{mm}$, followed by sclerotia of isolate SNG Rs-03 which is measured 1.6
$(1.3-1.8) \times 1.1(1.0-1.2) \mathrm{mm}$. Sclerotia of Isolate DNG Rs-06 from dungarpur showed size $1.3(1.1-1.5) \times 0.7(0.6-0.9) \mathrm{mm}$ and those of BNS Rs-05 measured $0.9(0.7-1.1) \times$ $0.3(0.2-0.6) \mathrm{mm}$ and the sclerotia of isolate UDP Rs-01 was the smallest in size and measuring $0.5(0.4-0.6) \times 0.3(0.1-0.4) \mathrm{mm}$ (Table-2). These results are agreement with the study of Padamini, (2014) and Fagodiya (2018) reported the isolate UDP Rs-01 had $90.0 \mathrm{~mm}$ colony diameter with $0.6 \times 10^{6}$ sclerotia/ $\mathrm{mm}$ and had velvety, suppressed, aerial growth, dull to dark black regular margins.

\section{Pathogenic variability}

The pathogenic variability of six isolates of $R$. solani from different locations was tested on susceptible cotton cultivar "Jai BG-II" under inoculated conditions. The maximum incidence 52.2 per cent was caused by SNG Rs-03 isolate followed by CHT Rs-04 (38.6 per cent) and 24.5 per cent by HMG Rs-02, while the lowest incidence was due to BNS Rs-05 which was 16.4 per cent. The maximum and high degree of symptoms was observed by SNG Rs-03 isolate with most of the roots rotting occurs at seedling stage and detached from the ground level with formation of brownish, large lesions on complete roots including pith and such plants were easily pooled out, that not have any secondary roots, while the symptoms of BNS Rs-05 isolate was showed rotten lesions were at just upper ground part, comparatively medium size lesions with pale yellowish in colour and has lower degree of symptoms (Table-3)

The isolate from Sri Ganganagar (SNG Rs03) was found more aggressive to cotton root rot compare to other isolates of $R$. solani; particularly causing maximum incidence during survey, more aggressive in growth characters with pathogenic potential in vitro 
and in vivo study, hence it was further used for in vitro study as well as in field experiments for integrated management of root rot of cotton.

\section{References}

Agriculture statistics at a glance-2016 (2017a\&b). Eands.dacnet.inc.in/PDF/glance2016pdf.

Anonymous, (2013-14). Economic Survey of India, Ministry of Finance (Economic Division).

Anonymous, (2016-17). Press Information Bureau, Govt. of India. http://pib.nic.in/newsite/mberel.aspx?rel id $=159082$

Belot, E.A. and Zimbiasi, H.L. (2007). Cotton disease loss estimate. Pages 165, 175 and 224 in proc. Belltwide cotton prod. Conference; National Cotton Council of America

Booth, C. (1971). The genus Fusarium. Commonwealth Mycological Institute, Kew, England. 16pp.

Fagodia, B.L. (2018). Biology and management of root rot of ajwain (Trachyspermum ammi L.) in southern Rajasthan. Ph.D. Thesis, MPUAT, Udaipur (Raj.).

Garcia, G.V. Onco, M.A.P and Susan, V.R. (2006). Review: biology and systematic of the formgenus Rhizoctonia. Spanish Journal of Aricultural Research. 4:5579.

Haq, I. Khan, S.M. and Ahmed, R. (1999). Physiological studies on six fungal isolates from rotted roots of cotton. Pakistan Journal of Phytopathology. 11: 173-177.

Heydary, A. Fattahi, H. Zamanizadeh, H. R. Hassanzadeh, N. (2005). Investigation on the possibility of using bacterial antagonists for biological control of cotton seedling damping-off in green house. Applied Entomology and
Phytopathology. 72: 51-69.

Holliday. 1981. Fungus diseases of tropical crops. Cambridge, U.K.: Cambridge University press, 1980 XVI. 607 pp.

Jagirdar, S.A.P. and Jagirdar, H.A. (1980). Cotton diseases in Sindh. Agricultural Research Institute. Tendojam.

Jiskani, M.M. (1992). Cotton diseases. Sindh Agriculture University, Tandojam. URL:http://WWW.Pakisthaneconomist. com/issue2001/issue27/i\&e4.htm.

Jiskani, M.M. (2001). Diseases of cotton and their control. Monthely "Sindh Agriculture". Agricultural Extension Sindh, Hydrabad. 2: 9-13.

Kamal, M. and Moghal, S.M. (1968). Studies on plant diseases of south west Pakistan. Agricultural Research Institute.Tandojam.

Koenning, S. (2008). Cotton seedling diseases. $\quad$ http://WWW.ces.ncsu. Edu/deptd/ pp/note/cotton. USA.

Michael, L. Bobby, B. Phipps, J. and Wrather, J.A. (2007). Cotton pests scouting and management. http://extension. Missouri.edu/explore/agguides/pests/ip $\mathrm{m}$.

Monga, D. and Sheo Raj. (1994). Cultural and pathogenic variations in the isolates of Rhizctonia species causing root rot of cotton. Indian Phytopathology. 47: 403407.

Mordue, J.E.M. (1988). International course on the identification of fungi and bacteria of agricultural importance. Commonwealth Mycological Institute. 69: 102-116.

Nawar, S.L. (2008). Control of root rot of green been with compost rice straw fortified with Trichoderma harzianum. American-Eurasian Journal of Agricultural \& Environmental Sciences. 3: 370-379.

Padamini, R. (2014). Studies on integrated management of wilt and root rot complex of chickpea (Cicer arietinum 
L.) caused by Fusarium spp. and Rhizoctonia solani. Ph.D. Thesis, MPUAT, Udaipur (Raj.).

Silva. A.G. Magsi, M.R. and Leghari, A.B. (1995). A survey of incidence of bollrot disease of cotton in Sindh. Pakisthan Journal of Phytopathology. 7: 206-207.

Singh, R. and Verma, J.P. (1988). Disease of cotton in India and their management. Rev. Tropical Plant Pathology. 5: 20754.
Sneh, B. (1992). Nonpathogenic isolates of Rhizoctonia spp. (np-R) and their role in biological control. Biology, Ecology, Pathology and Disease Control. Pp. 473-483.

Watkins, G.M. (1981). Compendium of cotton diseases. American Phytopathological society Aps press, 87 Pp.

Weiss, E.A. (2000). Oil seed crops. $1^{\text {st }}$. Edn. Belckwell Science, USA, 568Pp.

\section{How to cite this article:}

Ramniwas Yadav, Kalpana Yadav, R. N. Bunker, Sushila Choudhary and Shankar Lal Yadav. 2020. Cultural and Pathogenic Variability of the Different Isolates of Rhizoctonia solani Causing Root Rot of Cotton Collected from Rajasthan. Int.J.Curr.Microbiol.App.Sci. 9(02): 2829-2838. doi: https://doi.org/10.20546/ijcmas.2020.902.322 